\title{
Design and Application of Alarm Light Circuit for Intelligent Management System of Coal Mine Equipment
}

\author{
Xingshan $\mathrm{LI}^{1, \mathrm{a}}$, Jian $\mathrm{Lu}^{2}$ \\ ${ }^{1}$ Luohe medical college, Luohe, 462000, China \\ ${ }^{2}$ Henan Polytechnic Institute, Nanyang, 473000, China \\ aemail:604141388@qq.com
}

Keywords: Coal mine blasting equipment, intelligentialize, single - chip microcomputer, alarm, directive, message

\begin{abstract}
The intelligent management of the coal mine blasting equipment storehouse can regulate the storage of the explosive material by the real-time monitoring(temperature, humidity, pressure and vibration) of the storage environment of the blasting equipment. Fingerprint identification was used for opening the door to verify, through the computer or mobile phone remote control, switch door behavior and real-time monitoring data by the computer system records for the record, set the alarm function to make the product more safe and reliable, design of the alarm circuit test run normal.
\end{abstract}

\section{System architecture}

The intelligent management system of the explosive device database is made up of the computer access control system( lower machine )installed on the database, the database in the server and the management terminal software ( management system or PC) in PC[1]. The management terminal software is set up to four kinds of users: the leader, the system administrator, the security officer, the warehouse keeper. As shown in Figure 1.

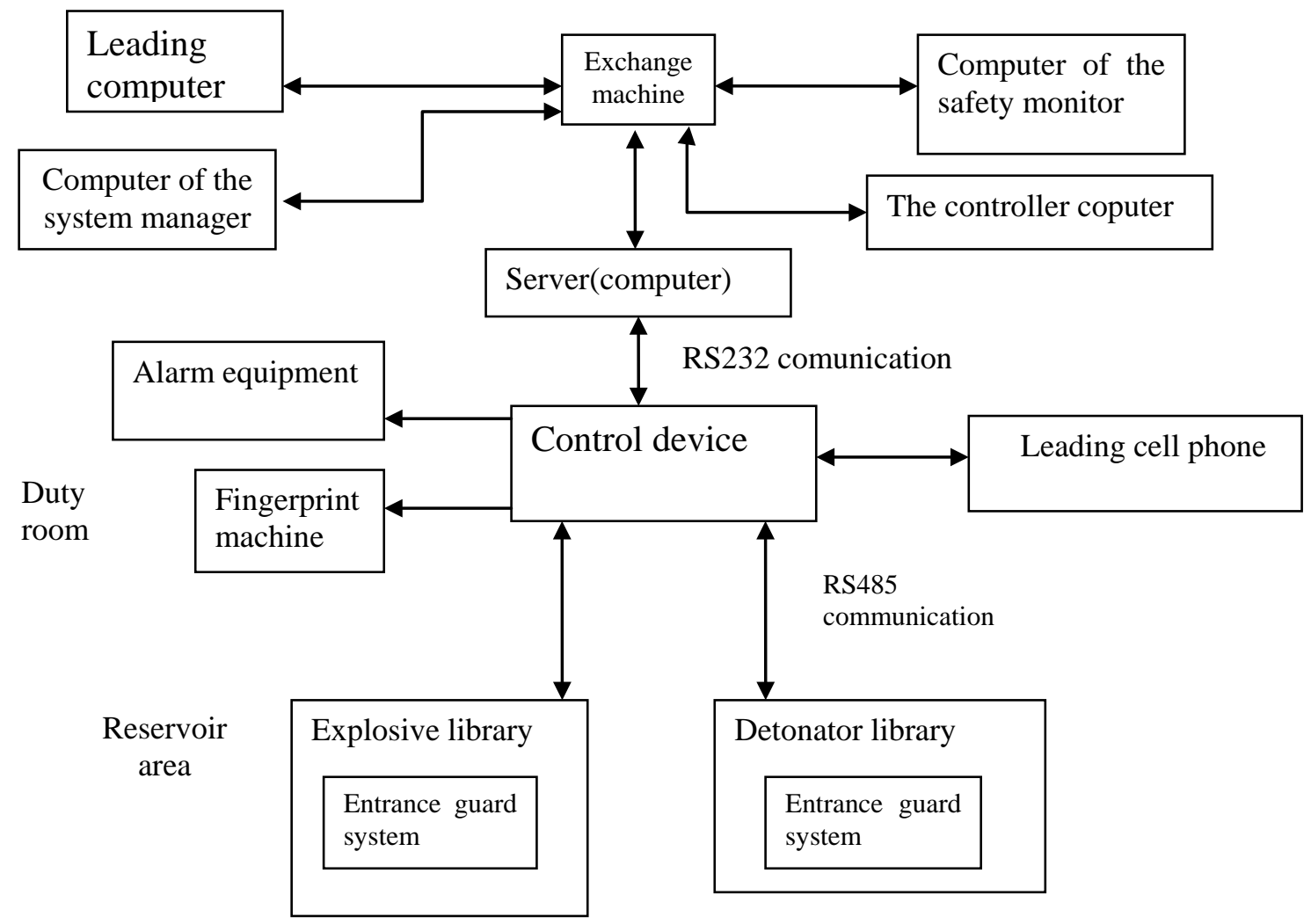

Fig.1. Intelligent management system architecture diagram of explosive magazine 


\section{Graphic description}

(1) The two box area of the lower part of the diagram are the area of the blasting equipment area, and the other area is the office area.

(2) Communication lines between the equipment in the reservoir area with the construction, the black line in the picture is a communication line, and the arrow represents the direction of data transmission

(3) The communication line between the reservoir area and the office area separate laying.

(4) The communication line in the reservoir area is twisted-pair, and if the distance between the reservoir and the office area is far away, it is difficult to lay,the fiber optic cable needed to use.

(5) Management terminal software of explosive devices needed to be installed in All PC , and the software of the terminal software can be assigned different operating rights according to different job responsibilities.

The monitoring and access management of explosive magazine and shot house in the reservoir area are controlled by the lower computer.The lower computer has the function of temperature and humidity, vibration response, time out alarm, fingerprint identification, electromagnetic lock control, data transmission and other functions, and it is controlled by single chip microcomputer[2]. System structure as shown in Fig. 2.

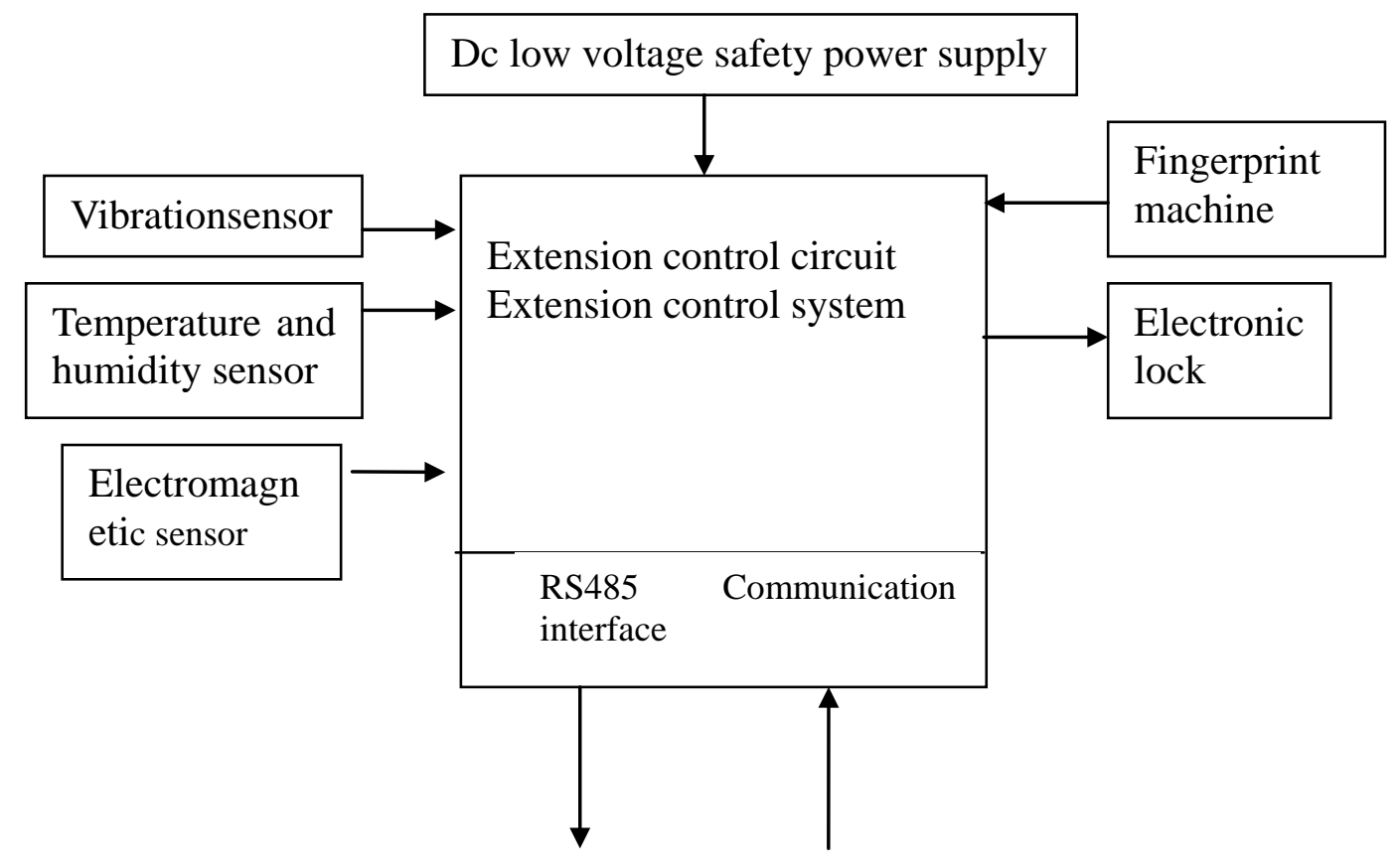

Fig.2. Lower computer system structure

In the duty room, there have a control device with stable performance. Its main function is to receive data from the lower computer and to send a lock command to the lower computer. The controller which use single-chip microcomputer technology can improve the reliability and security of the whole system. The main functions are fingerprint identification, information processing ability, data receiving and sending, alarm function, GSM communication, PC communication, human-computer interaction, etc. The function of network management and control can be achieved through server and server connectionin in the duty room. The function of single computer management and control can be achieved by a single computer and the controller connection, including the development and research of communication protocol, the design of authorization mode, the real time record of environmental parameters, and the development of the function of the record of explosive devices, the alarm record and the system fault self diagnosis. PC system to adopt C/S architecture, friendly interface, easy to control, the main function has a record of warehouse management, user management, temperature and humidity real-time, library door status real-time monitoring, inventory management, rights management, line condition monitoring, log 
management, query statistics, report forms printing, system configuration parameters, etc[3] .

\section{Alarm, indicator light interface circuit}

Circuit structure as shown in Figure 3

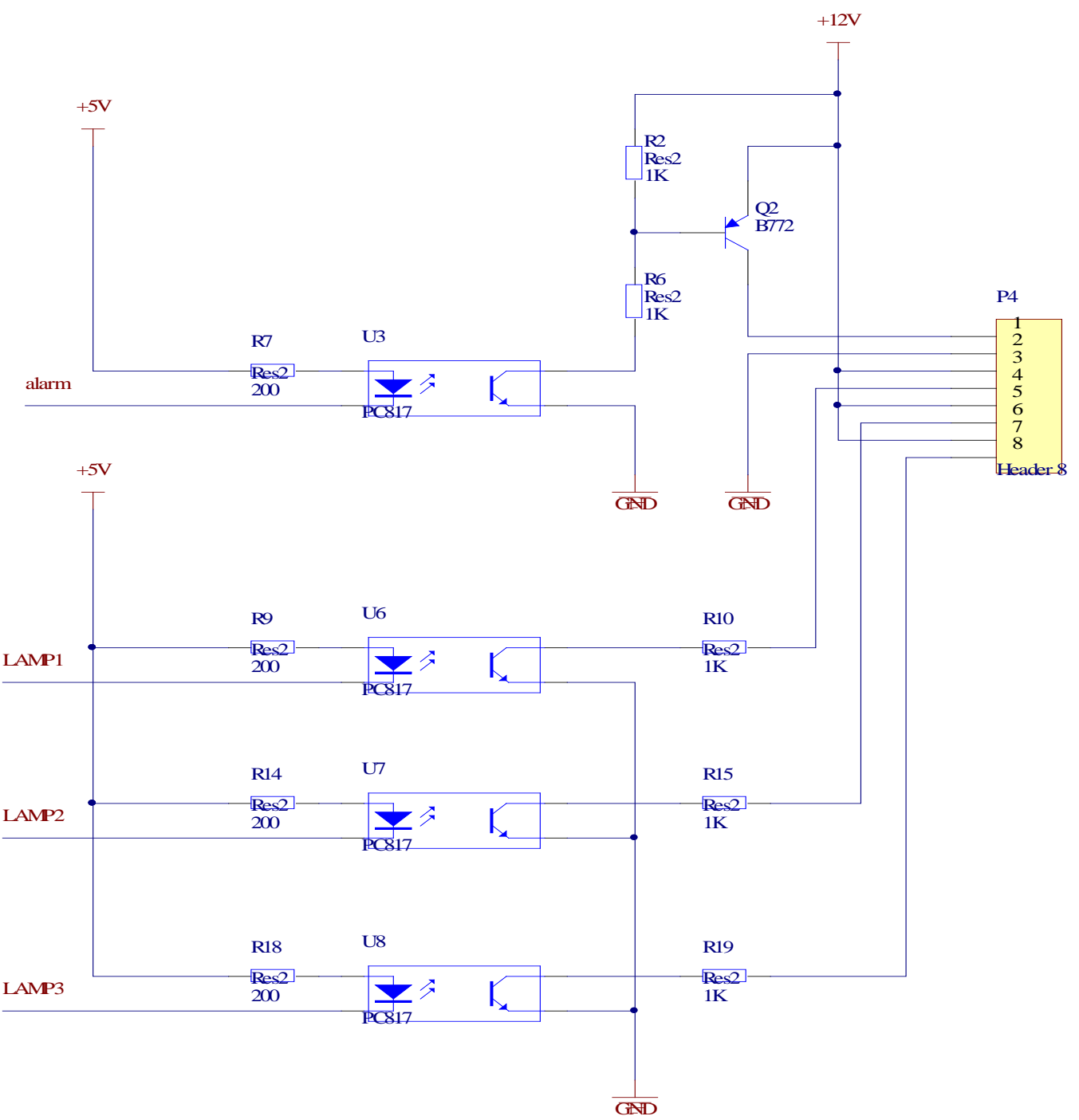

Fig.3. Alarm, indicator light interface circuit

System may be due to some kind of accident, caused by the alarm, the alarm processing can not be a simple release, you must ask the user will cause the alarm event processing is completed, and then to lift. Alarm mode mobile phone, alarm, software tips[4].

When the system caused alarm for temperature, pressure, humidity ,overrun or door vibration, warehouse immediately send alarm information to the warehouse management, alarm information immediate entry in the database, then the alarm management software pop-up dialog box in the end, a speaker sound alarm. At the same time when the leadership can be sent to view and handle. Then click on the corresponding button to release the alarm,at the same time any alarm instructions are also recorded in the database $\log [5]$.

\section{System alarm and emergency mechanism}

\section{Alarm generation.}

After the system alarm behavior, and the warehouse connection of the horn will be issued a piercing scream, through this sound, we can conclude that the system has produced an alarm. At the same time, the alarm system will prompt the alarm information in the background management software.Chart as below. 


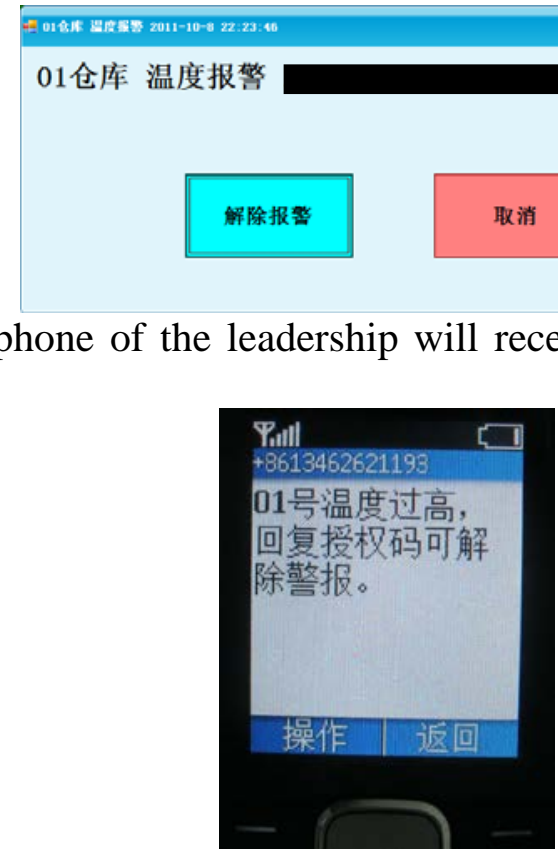

\section{Relieve alarm.}

In addition, the mobile phone of the leadership will receive a text message, the content is as follows:

If you want to lift the alarm, you can through the background management software, or by the leadership of the phone back to the authorized code two ways to lift the alarm.

(1) Background management software to lift the alarm

Such as figure, when the leader in front of the computer, you can click on the lifting of the alarm, directly lifted.

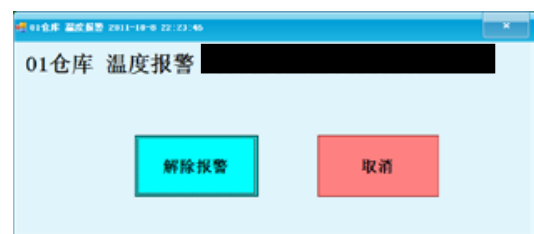

(2) Leader mobile phone to lift the alarm

If the leader is not in front of the computer, after receiving the mobile phone alarm message, you can reply to a set of pre - message authorization code can also lift the alarm.

\section{Part program for circuit operation}

// Send SMS alarm message according to categories

void GSM_SEND_ALARM(unsigned char GSM_CLASS_NUM)

\{ unsigned char xdata FLAG_GSM_SEND_OK=0,SEND_TEL_ii;

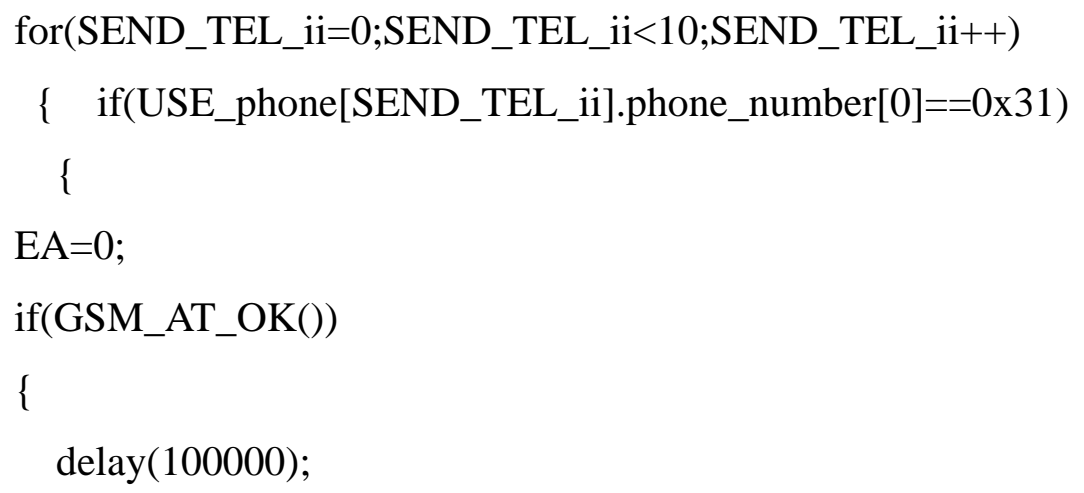

Delect_allmsg(); 


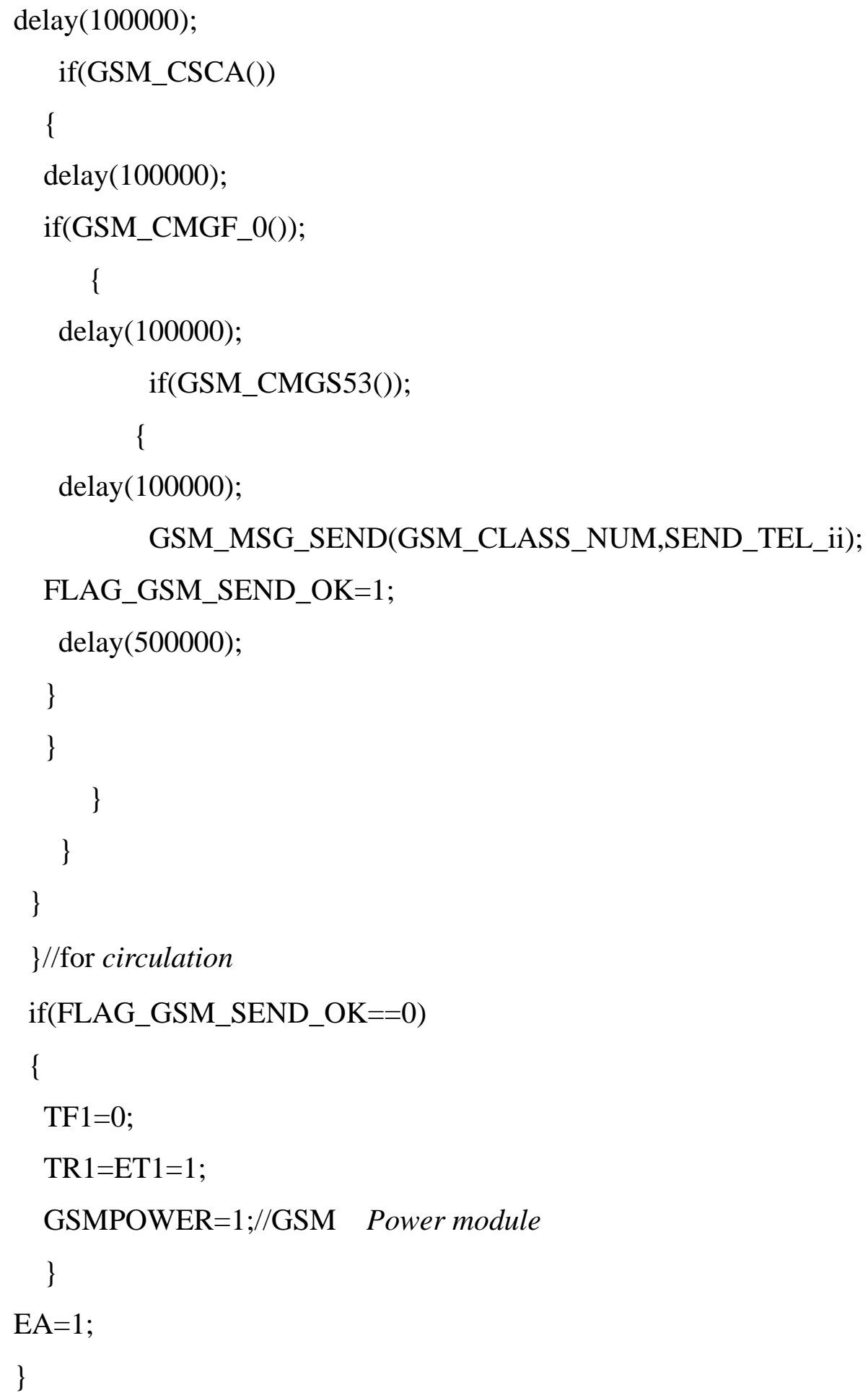

\section{Conclusion}

The result of the testing is in Table 1. The experimental parameters of the Alarm and Light circuit design meet the requirements.

Alarm circuit design of the intelligent management system of coal mine blasting equipment can reach the expected parameters after many experiments, Intelligent control for the storage and access of the explosive devices is realized, in the case of unattended, When an exception occurs, automatic sound and light alarm and send text messages to lift the alarm in time, so that the system is more safe and reliable. 
Table1: Testing project and phenomenon of explosive magazine control system

\begin{tabular}{|c|c|c|c|}
\hline $\begin{array}{l}\text { Serial } \\
\text { numb } \\
\text { er }\end{array}$ & Testing item & Testing phenomenon $\quad($ note: failure $\times$; passing: $\sqrt{ }$ ) & $\begin{array}{l}\text { Testing } \\
\text { result }\end{array}$ \\
\hline 1 & power-on test & system indicator lights are put out after flashing for about 5 seconds & $\sqrt{ }$ \\
\hline 2 & $\begin{array}{l}\text { threshold } \\
\text { Settings }\end{array}$ & $\begin{array}{l}\text { Whether parameter stting can be conducted to the hardware setting in } \\
\text { terms of new temperature, humidity, air pressure, door opening timeout } \\
\text { and authorization timeout. }\end{array}$ & $\sqrt{1}$ \\
\hline 3 & $\begin{array}{l}\text { Setting of the cell } \\
\text { phone users }\end{array}$ & $\begin{array}{l}\text { The possibility of adding, deleting, checking mobile phone number and } \\
\text { authorization code to the system }\end{array}$ & $\sqrt{1}$ \\
\hline 4 & $\begin{array}{l}\text { Alarm sounding } \\
\text { for unauthorized } \\
\text { entrance }\end{array}$ & $\begin{array}{l}\text { The possibility of the occurrence of alarm sounding for illegal entrance } \\
\text { and of clearing the alarm at the time of prompting by the short message of } \\
\text { the cell phone }\end{array}$ & $\sqrt{1}$ \\
\hline 5 & $\begin{array}{l}\text { Alarm sounding } \\
\text { on the occasion } \\
\text { of overtime } \\
\text { opening of the } \\
\text { door }\end{array}$ & $\begin{array}{l}\text { The short message can clear the alarm on the occasion of overtime } \\
\text { opening of the door and the prompting of the short message }\end{array}$ & $\sqrt{ }$ \\
\hline 6 & $\begin{array}{l}\text { Opening of } \\
\text { the door } \\
\text { authorized by the } \\
\text { cell phone }\end{array}$ & $\begin{array}{l}\text { Whether the system can dial the cell pone and whether the cell phone can } \\
\text { authorize normally authorize opening of the door }\end{array}$ & $\sqrt{ }$ \\
\hline 7 & Reset operation & $\begin{array}{l}\text { Whether the system can be automatically reset to factory defaults, the } \\
\text { reminder-light of the system are put out after flashing for about } 5 \text { seconds }\end{array}$ & $\sqrt{1}$ \\
\hline 8 & $\begin{array}{ll}\text { Resetto } & \text { Factory } \\
\text { Defaults }\end{array}$ & $\begin{array}{l}\text { Reset to Factory Defaults and the reminder-light of the system are put out } \\
\text { after flashing for about } 5 \text { seconds }\end{array}$ & t \\
\hline
\end{tabular}

\section{Acknowledgement}

In this paper, the research was sponsored by the Research Subject of Henan Province Education Technology and Equipment and Practice Education(GZS112).

\section{Reference}

[1] Cai CW,Fan HJ,Liu BY.Design and Application of Gate Control System Based on Fingerprint Identification Technology [J] .Video Engineering, 2012,36(3): 128-130.

[2] Zhong XY,Wang BQ,Li B.Design of apparatus-cabinet controller based on EPM7128SLC84[J].Journal Of Modern Electronics Technique,2006,29(1):110-112.

[3] Zhao L.Design of alarm system based on photoelectric sensor[J].Electronic test,2013,9(9): 25-26.

[4] Sun J. The Family guard against theft and alarm system based on GSM Modem[J]. Shanxi science and technology, 2014,29 (4):152-154.

[5] Li ST. Design of acoustic alarm based on Single-chip Microcomputer [J]. Journal of Shangluo University, 2015,29 (4):11-14. 